\title{
Cakupan Imunisasi Dasar Lengkap dan Faktor yang Memengaruhi
}

\author{
Ika Citra Dewi Tanjung, Lili Rohmawati, Sri Sofyani \\ Bagian Ilmu Kesehatan Anak Fakultas Kedokteran Universitas Sumatera Utara/RSUP Haji Adam Malik, Medan
}

Latar belakang. Imunisasi merupakan salah satu upaya perlindungan kesehatan yang paling efektif untuk anak-anak terhadap beberapa penyakit yang dapat dicegah dengan imunisasi (PD3I). Keberhasilan pelaksanaan program imunisasi di Indonesia dipengaruhi oleh beberapa faktor, antara lain, usia ibu, tingkat pendidikan ibu, status pekerjaan ibu, tingkat pengetahuan ibu dan urutan kelahiran anak. Tujuan. Mengetahui cakupan imunisasi dasar lengkap pada anak dan menilai faktor-faktor yang memengaruhinya.

Metode. Penelitian ini deskriptif analitik dengan desain cross sectional yang dilakukan di Divisi Tumbuh Kembang dan Pediatri Sosial, Departemen Ilmu Kesehatan Anak RSUP H. Adam Malik Medan, mulai bulan Oktober 2015 sampai April 2016. Data diambil dari rekam medis pasien rawat jalan dan rawat inap. Data diolah dengan statistik deskriptif dan disajikan dalam bentuk distribusi frekuensi dan faktor yang memengaruhi kelengkapan imunisasi dasar dianalisis dengan menggunakan uji regresi logistik.

Hasil. Di antara 113 sampel penelitian didapatkan 46 orang (40,7\%) memiliki status imunisasi dasar lengkap. Faktor yang memengaruhi kelengkapan imunisasi dasar adalah pemberian ASI eksklusif ( $\mathrm{p}=0,017$ ). Jenis kelamin, status nutrisi, cara lahir, berat badan lahir, pendidikan ibu, pekerjaan ibu, urutan kelahiran, jumlah anak dan usia ibu tidak memengaruhi kelengkapan imunisasi dasar anak. Kesimpulan. Cakupan imunisasi dasar lengkap pada anak 40,7\% dan faktor yang memengaruhi kelengkapan imunisasi dasar adalah pemberian ASI eksklusif. Sari Pediatri 2017;19(2):86-90

Kata kunci: anak, imunisasi dasar lengkap, faktor-faktor yang memengaruhi

\section{Complete Basic Immunization Coverage in Children and the Factors Influencing It}

Ika Citra Dewi Tanjung, Lili Rohmawati, Sri Sofyani

Background. Immunization is one of the most cost effective healthcare to protect children against some preventable diseases. The successful implementation of the immunization program in Indonesia influenced by several factors among others birth order, maternal age, maternal education, maternal knowledge and maternal occupation.

Objective. This study was to identify complete basic immunization coverage in children and the factors influencing it.

Methods. An analytic descriptive research with cross sectional design was conducted in the Growth Developmental and Social Pediatrics Division, Department of Child Health, Haji Adam Malik General Hospital, Medan from October 2015 to April 2016. Data were collected from outpatient and inpatient medical records. Data was analyzed with descriptive statistic and presented in the form of frequency distribution and factors influencing completeness of basic immunization were analyzed with logistic regression test.

Result. Among 113 children, we obtained 46 children (40.7\%) with complete basic immunization. The factor influencing completeness basic immunization was exclusive breastfeeding $(\mathrm{P}=0.017)$. Whereas sex, nutritional status, birth methods, birth body weight, maternal education, maternal occupation, birth order, number of children and maternal age were not influencing it.

Conclusion. Complete basic immunization coverage in children was $40.7 \%$ and the factor influencing completeness basic immunization was exclusive breastfeeding. Sari Pediatri 2017;19(2):86-90

Keywords: children, complete basic immunization, factors influencing

Alamat korespondensi: Dr. Ika Citra Dewi Tanjung, M. Ked(Ped), SpA. Staf Divisi Tumbuh Kembang dan Pediatri Sosial Departemen Ilmu Kesehatan Anak Fakultas Kedokteran USU/ RSUP H. Adam Malik Medan. Email: ikacdt@yahoo.com 
S etiap tahun, lebih dari 1,4 juta anak di dunia meninggal karena berbagai penyakit yang sebenarnya dapat dicegah dengan imunisasi. ${ }^{1}$ Imunisasi merupakan salah satu usaha yang paling efektif dan banyak dilakukan untuk mencegah kematian anak. ${ }^{2}$ Imunisasi melindungi anak terhadap beberapa penyakit yang dapat dicegah dengan imunisasi (PD3I), seperti tuberkulosis, difteri, tetanus, hepatitis B, pertusis, campak, polio, radang selaput otak, dan radang paru-paru. ${ }^{1}$

Program imunisasi dasar lengkap menurut Peraturan Menteri Kesehatan Republik Indonesia no. 42 tahun 2013 wajib diberikan pada bayi sebelum berusia satu tahun, yang terdiri dari Bacillus Calmette Guerin (BCG), diphtheria pertussis Tetanus-Hepatitis B-haemophillus influenzae tipe B (DPT-HB-HiB), hepatitis B pada bayi baru lahir, polio dan campak. ${ }^{3}$

Keberhasilan program imunisasi dapat memberikan cakupan imunisasi yang tinggi dan memelihara imunitas yang ada di masyarakat. Namun, cakupan imunisasi dasar dipengaruhi oleh berbagai faktor, ${ }^{4}$ antara lain, sikap petugas, lokasi imunisasi, kehadiran petugas, usia ibu, tingkat pendidikan ibu, tingkat pendapatan keluarga per bulan, kepercayaan terhadap dampak buruk pemberian imunisasi, status pekerjaan ibu, tradisi keluarga, tingkat pengetahuan ibu, dan dukungan keluarga. ${ }^{5}$

Data dalam profil kesehatan Indonesia, cakupan imunisasi dasar lengkap 86,9\%, dan Sumatera Utara $79,9 \%$ pada tahun 2014, belum mencapai target rencana strategis (Renstra) tahun 2014 sebesar $90 \%{ }^{1}$ Penelitian di Padang tahun 2013 didapatkan cakupan imunisasi dasar lengkap sebesar $57,1 \%$, dan hal ini dipengaruhi oleh tingkat pengetahuan ibu dengan rasio odds sebesar $154 .^{6}$

Divisi Tumbuh Kembang dan Pediatri Sosial, Departemen Ilmu Kesehatan Anak RSHAM belum mempunyai data cakupan imunisasi dasar lengkap dan faktor-faktor yang memengaruhinya, karena itu penelitian ini dilakukan.

Tujuan penelitian untuk mengetahui cakupan imunisasi dasar lengkap pada anak dan menilai faktorfaktor yang memengaruhinya.

\section{Metode}

Penelitian deskriptif analitik dengan desain cross sectional yang dilakukan di Poliklinik Tumbuh
Kembang dan Pediatri Sosial RSUP H. Adam Malik Medan. Waktu penelitian selama 7 bulan, mulai bulan Oktober 2015 sampai April 2016. Sampel penelitian diambil dari rekam medis Divisi Tumbuh Kembang dan Pediatri Sosial Departemen Ilmu Kesehatan Anak FK USU/ RSUP H. Adam Malik Medan, yaitu semua anak usia nol bulan sampai dengan 60 bulan, secara randomisasi dengan besar sampel 113 orang.

Penelitian ini telah disetujui oleh Komite Etik dari Fakultas Kedokteran Universitas Sumatera Utara. Cara kerja penelitian dengan mengumpulkan data dari rekam medis pasien, antara lain, nama, jenis kelamin, usia, berat badan, tinggi badan, pendidikan ibu, pekerjaan ibu, urutan kelahiran anak, berat badan lahir, pemberian ASI eksklusif, dan imunisasi dasar. Jika data dari rekam medis tidak lengkap, akan dieksklusikan. Data yang diperoleh dianalisis dengan menggunakan program SPSS versi 21.0, semua variabel akan dianalisis dengan statistik deskriptif dan disajikan dalam bentuk distribusi frekuensi, sedangkan faktor-faktor yang memengaruhi kelengkapan imunisasi dasar pada anak dianalisis dengan menggunakan uji regresi logistik dan dikatakan bermakna secara statistik bila nilai $\mathrm{p}<0,05$.

\section{Hasil}

Jumlah sampel yang memiliki imunisasi dasar lengkap $46(40,7 \%)$ dengan mayoritas sampel penelitian adalah laki-laki $(54,3 \%)$ dan lebih banyak anak yang mendapat ASI eksklusif (52,2\%), berbeda dengan kelompok imunisasi dasar tidak lengkap. Pada kedua kelompok didapatkan frekuensi terbanyak dalam hal status nutrisi normal, cara lahir spontan, berat lahir 2 500-4 000 gram, ibu dengan pendidikan tinggi, ibu tidak bekerja, anak pertama, jumlah anak satu dan usia ibu lebih dari atau sama dengan 30 tahun. Data karakteristik sampel penelitian tertera pada Tabel 1 .

\section{Pembahasan}

Penelitian ini menunjukkan cakupan imunisasi dasar lengkap rendah 40,7\%. Hasil ini tidak jauh berbeda dengan cakupan imunisasi dasar lengkap di Padang tahun $2013(57,1 \%) .{ }^{6}$ Kedua penelitian ini masih belum mencapai target rencana strategis (Renstra) tahun 2014 yang sebesar $90 \% .^{1}$ Penyebab cakupan 
Ika Citra Dewi Tanjung dkk: Cakupan imunisasi dasar lengkap dan faktor yang memengaruhi

Tabel 1. Karakteristik dasar sampel penelitian dan faktor yang memengaruhi kelengkapan imunisasi dasar

\begin{tabular}{|c|c|c|c|}
\hline \multirow[b]{2}{*}{ Variabel } & \multicolumn{2}{|c|}{ Imunisasi dasar } & \multirow[b]{2}{*}{$\mathrm{p}$} \\
\hline & $\begin{array}{l}\text { Lengkap } \\
(\mathrm{n}=46)\end{array}$ & $\begin{array}{c}\text { Tidak lengkap } \\
(n=67)\end{array}$ & \\
\hline \multicolumn{4}{|l|}{ Jenis kelamin, $\mathrm{n}(\%)$} \\
\hline Laki-laki & $25(54,3)$ & $33(49,3)$ & 0,187 \\
\hline Perempuan & $21(45,7)$ & $34(50,7)$ & \\
\hline \multicolumn{4}{|l|}{ Status nutrisi, n (\%) } \\
\hline Sangat kurus & $4(8,7)$ & $21(31,3)$ & 0,062 \\
\hline Kurus & $12(26,1)$ & $10(14,9)$ & \\
\hline Normal & $27(58,7)$ & $34(50,7)$ & \\
\hline Gemuk & $3(6,5)$ & $2(3,0)$ & \\
\hline \multicolumn{4}{|l|}{ Cara lahir, n (\%) } \\
\hline Spontan & $34(73,9)$ & $43(64,2)$ & 0,272 \\
\hline Seksio caesaria & $12(26,1)$ & $24(35,8)$ & \\
\hline \multicolumn{4}{|c|}{ Berat lahir dalam gram, n (\%) } \\
\hline$<2500$ & $4(8,7)$ & $11(16,4)$ & 0,879 \\
\hline $2500-4000$ & $40(87,0)$ & $56(83,6)$ & \\
\hline$>4000$ & $2(4,3)$ & $0(0)$ & \\
\hline \multicolumn{4}{|l|}{ ASI eksklusif, n (\%) } \\
\hline Ya & $24(52,2)$ & $16(23,9)$ & $0,017^{*}$ \\
\hline Tidak & $22(47,8)$ & $51(76,1)$ & \\
\hline \multicolumn{4}{|l|}{ Pendidikan ibu, n (\%) } \\
\hline Rendah & $9(19,6)$ & $23(34,3)$ & 0,062 \\
\hline Tinggi & $37(80,4)$ & $44(65,7)$ & \\
\hline \multicolumn{4}{|l|}{ Pekerjaan ibu, n (\%) } \\
\hline Bekerja & $10(21,7)$ & $14(20,9)$ & 0,503 \\
\hline Tidak bekerja & $36(78,3)$ & $53(79,1)$ & \\
\hline \multicolumn{4}{|c|}{ Urutan kelahiran, $\mathrm{n}(\%)$} \\
\hline Anak pertama & $21(45,7)$ & $25(37,3)$ & 0,086 \\
\hline Anak kedua & $15(32,6)$ & $16(23,9)$ & \\
\hline Anak ketiga & $9(19,6)$ & $11(16,4)$ & \\
\hline Anak keempat dst & $1(2,1)$ & $15(22,4)$ & \\
\hline \multicolumn{4}{|l|}{ Jumlah anak, n (\%) } \\
\hline Satu & $19(41,3)$ & $23(34,3)$ & 0,500 \\
\hline Dua & $12(26,1)$ & $17(25,4)$ & \\
\hline Tiga & $14(30,4)$ & $12(17,9)$ & \\
\hline Empat atau lebih & $1(2,2)$ & $15(22,4)$ & \\
\hline \multicolumn{4}{|c|}{ Usia ibu dalam tahun, $\mathrm{n}(\%)$} \\
\hline $15-19$ & $0(0)$ & $1(1,5)$ & 0,242 \\
\hline $20-24$ & $4(8,7)$ & $16(23,9)$ & \\
\hline $25-29$ & $18(39,1)$ & $19(28,4)$ & \\
\hline$\geq 30$ & $24(52,2)$ & $31(46,3)$ & \\
\hline
\end{tabular}

*Uji regresi logistik 
imunisasi dasar lengkap yang rendah dipengaruhi oleh banyak faktor. Faktor yang berpengaruh maupun yang tidak berpengaruh terhadap kelengkapan imunisasi dasar dapat dijelaskan sebagai berikut.

Jumlah anak laki-laki dan perempuan yang mendapat imunisasi dasar lengkap tidak jauh berbeda sehingga jenis kelamin tidak memengaruhi kelengkapan imunisasi dasar pada anak. Hal ini sesuai dengan penelitian di kota Al-Beida, Libya tahun $2008,{ }^{7}$ karena anak laki-laki dan perempuan harus mendapatkan perlindungan yang sama dari kesakitan dan kematian akibat penyakit yang dapat dicegah dengan imunisasi.

Status nutrisi dinilai dari berat badan menurut tinggi badan $(\mathrm{BB} / \mathrm{TB})$ yang merupakan salah satu indikator penilaian pertumbuhan anak. Didapatkan status nutrisi tidak memengaruhi kelengkapan imunisasi dasar. Hasil ini berbeda dengan penelitian di Tangerang tahun 2016 yang menunjukkan adanya hubungan pertumbuhan anak Toddler dengan kelengkapan imunisasi dasar. ${ }^{8}$ Perbedaan tersebut karena anak dengan status nutrisi sangat kurus dan kurus tetap mendapat imunisasi meskipun pemberiannya ditunda sampai anak mencapai status nutrisi normal, agar pembentukan imunitas tubuh lebih baik setelah imunisasi.

Cara lahir anak tidak memengaruhi kelengkapan imunisasi dasar. Jumlah anak yang lahir secara spontan lebih banyak dari sectio caesaria, tetapi memiliki kesempatan yang sama untuk memperoleh imunisasi dasar lengkap. Kepustakaan atau penelitian lain belum ada yang membahas pengaruh cara lahir terhadap kelengkapan imunisasi dasar.

Kepustakaan menyebutkan untuk anak dengan berat lahir rendah (kurang dari 2500g) tetap diberikan imunisasi meskipun pemberiannya ditunda sampai berat badan sudah mencapai 2000g. ${ }^{9}$ Pada penelitian ini anak dengan berat lahir rendah memiliki imunisasi dasar lengkap meskipun jumlahnya sedikit $(8,7 \%)$. Namun, berat lahir tidak memengaruhi status kelengkapan imunisasi dasar karena anak dengan berat lahir rendah, normal, dan lebih tetap dapat memperoleh imunisasi dasar lengkap.

Air susu ibu (ASI) eksklusif adalah ASI yang diberikan pada bayi dari lahir sampai usia enam bulan tanpa menambahkan dan atau menggantikan dengan makanan dan minuman lain. ${ }^{10}$ Pada penelitian ini pemberian ASI eksklusif memengaruhi kelengkapan imunisasi dasar. Alasan pemberian ASI eksklusif memengaruhi kelengkapan imunisasi dasar belum diketahui.

Pendidikan ibu merupakan salah satu faktor yang memengaruhi kelengkapan imunisasi dasar. Semakin tinggi pendidikan seorang ibu, maka pengetahuan ibu tentang imunisasi lebih baik. Penelitian ini menunjukkan pendidikan ibu tidak memengaruhi kelengkapan imunisasi dasar anak. Hasil ini sesuai dengan penelitian di Surabaya tahun $2013,{ }^{11}$ anak yang mendapat imunisasi dasar lengkap dan tidak lengkap sebagian besar memiliki ibu dengan pendidikan tinggi. Namun, berbeda dengan penelitian di Distrik Jigjiga, Etiopia tahun 2011 yang melaporkan bahwa pendidikan ibu akan memberikan efek positif terhadap kelengkapan imunisasi anak. ${ }^{12}$

Pekerjaan ibu dibagi menjadi bekerja dan tidak bekerja. Ibu tidak bekerja memiliki waktu yang lebih banyak dan fleksibel untuk membawa anaknya imunisasi, tetapi pekerjaan ibu tidak memengaruhi kelengkapan imunisasi dasar. Hasil ini sesuai dengan penelitian di Surabaya tahun 2013, ${ }^{11}$ antara anak yang mendapat imunisasi dasar lengkap dan tidak lengkap sebagian besar memiliki ibu yang tidak bekerja.

Anak pertama cenderung mendapat perhatian lebih banyak dari orangtua. Pada penelitian ini, urutan kelahiran tidak memengaruhi kelengkapan imunisasi dasar. Hasil ini tidak sesuai dengan penelitian di Distrik Arbegona, Etiopia bagian Utara tahun 2014 yang melaporkan bahwa urutan kelahiran kedua sampai keempat dan urutan kelahiran kelima serta selanjutnya memiliki imunisasi dasar tidak lengkap dibandingkan dengan anak pertama ${ }^{13}$ karena jumlah anak pertama pada kedua kelompok tidak jauh berbeda.

Jumlah anak tidak memengaruhi kelengkapan imunisasi dasar. Hasil ini tidak sesuai dengan penelitian di Makassar tahun 2014 yang melaporkan bahwa jumlah anak yang cukup akan berdampak positif terhadap ibu untuk mengimunisasi anaknya dengan lengkap ${ }^{14}$ karena jumlah anak yang lebih sedikit dijumpai pada kelompok imunisasi dasar tidak lengkap.

Usia menunjukkan tingkat kematangan berpikir seseorang. Pengalaman seorang ibu akan bertambah dalam mengasuh anak seiring dengan bertambahnya usia. Dalam penelitian ini, sebagian besar usia ibu lebih dari atau sama dengan 30 tahun, tetapi usia ibu tidak memengaruhi kelengkapan imunisasi dasar anak, karena pada kedua kelompok sebagian besar usia ibu lebih dari atau sama dengan 30 tahun. Hal ini sesuai dengan penelitian di Kendal tahun 2013 
yang melaporkan bahwa tidak ada hubungan antara usia ibu dengan imunisasi dasar lengkap. ${ }^{15}$ Namun berbeda dengan penelitian di Distrik Jigjiga, Etiopia tahun 2011 yang melaporkan bahwa ibu yang usianya lebih tua akan mengimunisasi anaknya dengan lengkap dibandingkan dengan ibu usia muda. ${ }^{12}$

\section{Kesimpulan}

Cakupan imunisasi dasar lengkap pada anak masih rendah yaitu $40,7 \%$ dan faktor yang memengaruhi kelengkapan imunisasi dasar adalah pemberian ASI eksklusif, sedangkan jenis kelamin, status nutrisi, cara lahir, berat badan lahir, pendidikan ibu, pekerjaan ibu, urutan kelahiran, jumlah anak dan usia ibu tidak memengaruhi kelengkapan imunisasi dasar. Perlu dilakukan penelitian lebih lanjut untuk menganalisis hubungan pemberian ASI eksklusif dengan kelengkapan imunisasi dasar.

\section{Daftar pustaka}

1. Yudianto, Budijanto D, Hardhana B, Soenardi TA. Profil Kesehatan Indonesia tahun 2014. Jakarta: Kementerian Kesehatan Republik Indonesia; 2015. h.119-20.

2. Negussie A, Kassahun W, Assegid S, Hagan AK. Factors associated with incomplete childhood immunization in Arbegona district, Southern Ethiopia: a case control study. BMC Pub Health 2016; 16:1-9.

3. Kementerian Kesehatan Republik Indonesia. Peraturan Menteri Kesehatan Republik Indonesia no 42 tahun 2013 tentang penyelenggaraan imunisasi. Jakarta: Kemkes RI;1992.

4. Bernsen RM, Al-Zahmi FR, Al-Ali NA, Hamaodi RO, Ali NA, Schneider J, dkk. Knowledge, attitude and practice towards immunizations among mothers in a traditional city in the United Arab Emirates. J Med Sci. 2011; 4:114-21.

5. Rahmawati AI, W UC. Faktor yang memengaruhi kelengkapan imunisasi dasar di kelurahan Krembangan Utara. J Berkala Epid 2014; 2:59-70.

6. Dewi AP, Darwin E, Edison. Hubungan tingkat pengetahuan ibu dengan pemberian imunisasi dasar lengkap pada bayi di kelurahan Parupuk Tabing wilayah kerja puskesmas Lubuk Buaya kota Padang tahun 2013. J Kes Andalas 2014; 3:114-8.

7. Mabrouka AM, Bofarraj. Knowledge, attitude and practices of mothers regarding immunization of infants and preschool children at Al-Beida city, Libya, 2008. Egypt J Pediatr Allergy Immunol 2011;9:29-34.

8. Hikmah, Riyantini Y, Wahyuni Y. Hubungan kelengkapan imunisasi dasar dengan tumbuh kembang toddler di Posyandu Bunga Padi di Kota Tangerang. JKFT 2016; 2:89-96.

9. Saari TN. Immunization of preterm and low birth weight infants. Pediatrics 2003;112:193-8.

10. Peraturan Pemerintah Republik Indonesia no 33 tahun 2012 tentang pemberian air susu ibu eksklusif. Diakses pada 18 September 2017. Didapat dari: http://jdih.pom.go.id/showpdf. php? $u=Z b m k w b A w f i P R n k 3 R U j P 4 t P E 9 j l \% 2 F M L C P n 4 z W M$ coe $7 H 20 \% 3 D$.

11. Rahmawati AI, Umbul C. Faktor yang memengaruhi kelengkapan imunisasi dasar di kelurahan Krembangan Utara. Jurnal Berkala Epidemiologi 2014;2:59-70.

12. Mohamud AN, Feleke A, Worku W, Kifle M, Sharma HR. Immunization coverage of 12-23 months old children and associated factors in Jigjiga district, Somali National Regional State, Ethiopia. BMC Pub Health 2014;14:1-9.

13. Negussie A, Karsahun W, Assegid S, Hagan AK. Factors associated with incomplete childhood immunization in Arbegona district, Southern Ethiopia: a case-control study. BMC Pub Health 2016;16:1-9

14. Makamban Y, Salmah U, Rahma. Factors associated with complete basic immunization coverage of infants in the working area of Puskesmas Antara, Makassar city. Diakses pada 18 September 2017. Didapat dari: http://repository.unhas.ac.id/ bitstream/handle/123456789/9518.

15. Nurani VA. Faktor-faktor yang berhubungan dengan kelengkapan imunisasi dasar pada bayi di desa Truko kecamatan Kangkung kabupaten Kendal tahun 2013, skripsi. Semarang: Fakultas Kesehatan Masyarakat UDINUS, 2014. 